\title{
Produk dan Lokasi Pengaruhnya Terhadap Keputusan Pembelian Melalui Harga Sebagai Variabel Intervening: Studi Pada Konsumen Pasar Tradisional
}

\author{
Muhamad Rifa'I, Kalista Siska Elisa, Retno Ayu Dewi Novitawati \\ Universitas Tribhuwana Tunggadewi Malang, Indonesia \\ Email corresponding author: rifaiunitri@gmail.com
}

\begin{abstract}
ABSTRAK
Pengambilan keputusan pembelian konsumen adalah penting untuk dipahami oleh produsen, sehingga perlu adanya upaya untuk selalu mempelajari tentang kebutuhan dan keinginan konsumen. Tujuan penelitian ini untuk mengetahui pengaruh produk dan lokasi terhadap keputusan pembelian konsumen melalui harga sebagai veriabel intervening di pasar tradisinoal. Sampel penelitian ini adalah pembeli pada pasar tradisional sebayak 100 responden yang ditentukan secara purposive sampling,teknik pengumpulan data yang digunakan adalah kuesioner. Analisa data yang di gunakan yaitu path analisis. Hasil penelitian menujukkanproduk, dan lokasi berpengaruh terhadap harga dan keputusan pembelian, harga dan lokasiberpengaruh terhadap keputusan pembelian, lokasi berpengeruh terhadap keputusan pembelian melalui harga. Adapun yang perlu di perhatikan pedagang yaitu menjual produk yang berkualitas baik dan menentukan harga produk sesuai kualitasnya.
\end{abstract}

Kata Kunci: Produk, lokasi, harga, keputusan pembelian

\section{PENDAHULUAN}

Pasar tradisional merupakan representasi dari ekonomi rakyat dan masyarakat ekonomi kelas bawah [1] sehingga keberadaan perlu dipertahankan ditengah-tengah serbuan pasar modern. Keberadaan pasar modern saat ini tumbuh dan berkembang dengan pesat di wilayah perkotaan, suasana pasar yang rapi, bersih dan nyaman membuat orang banyak tertarik berbelanja di pasar modern[2]. Timbulnya pasar modern ini disebakan oleh adanya satandar hidup dan gaya hidup masyarakat [3], hal ini lebih disebabkan karena konsumen ingin mendapatkan pelayanan yang baik.

Seiring dengan itu, tidak dapat dipungkiri bahwa keberadaan pasar modern telah menjadi tuntutan dan konsekuensi dari gaya hidup modern yang berkembang dalam masyarakat kita [4]. Dengan menawarkan variasi produk, kualitas produk yang baik, Fasilitas yang baik, kenyamanan yang telah membuat banyak dari pasar modern memiliki keunggulan kompetitif yang lebih baik dibandingkan dengan pasar tradisional. Jadi tidak salah jika mereka dapat berkembang dan memikat masyarakat begitu cepat [5]. Dampak negatif yang munculyaitu pada pedagang kecil di pasar tradisional yaitu mengurangi daya beli tanpa menciptakan dinamisme 
ekonomi lokal, pemasok tekanan, tenaga kerja, demokrasi, budaya, Asing, konsumerisme, dan lingkungan [6].

Perkembangan pasar modern yang begitu pesat memberikan dampak yang secara langsung maupuntidak langsung terhadap pasar tradisional selaku pemain lama dalam industri ritel nasional[7]. Namun keberdaan pasar tradisional juga masih banyak diminati oleh masyarakat, bagi kehidupan masyarakat perkotaan dan pedesaan keberadaan pasar tradisional telah menjadi bagian penting[8]. Hal ini menjadi nilai budaya yang menawarkan kegiatan perdagangan yang meluas seperti perhotelan dalam transaksi untuk mencapai kesepakatan harga[9].Pasar tradisional masih menjadi wadah utama penjualan barang pokok yang diproduksi oleh pelaku ekonomi skala kecil dan mikro. Mereka adalah petani, nelayan, pengrajin dan industri rumahan (industri rakyat). Jumlah mereka adalah puluhan juta dan sangat bergantung pada pasar tradisional[10].

Pasar tradisional merupakan tempat di luar ruangan, yang proses pembelian dan penjualan dengan proses tawar-menawar, dimana Pasar tradisional memiliki karakteristik tempat itu tidak terlalu luas, barang yang dijual tidak terlalu banyak jenis, sistem manajemen masih sederhana, tidak menawarkan kenyamanan belanja. Masih ada harga tawar-menawar dengan pedagang, produk yang dijual tidak pada layar terbuka sehingga pelanggan tidak menentukan apakah pengecer memiliki item yang dicari atau tidak[11].Menurut Permendag nomor 53 tahun 2008 tentang Pedoman Penataan dan Pembinaan Pasar Tradisional, Pusat Perbelanjaan dan Toko Modern, menjelaskanpasar tradisional merupakan suatu tempat usaha yang terdiri dari los, kios dan toko yang dibangun di tanah milik pemerintah dan di miliki oleh pedagang skala kecil dan menengah dengan transaksi secara tawar menawar.Pada umumnya pasar tradisional menyediakan bahan-bahan pokok serta keperluan rumah tangga. Bangunan pasar tradisional biasanya terdiri dari kios-kios atau gerai, los, dan dasaran terbuka yang dibuka oleh penjual maupun suatu pengelola pasar.Pasar tradisional adalah wadah untuk mendapatkan berbagai kebutuhan dan kebutuhan dasar mayoritas masyarakat di negeri ini. Mereka bisa mendapatkannya dengan harga terjangkau. Hal Ini merupakan keuntungan pasar tradisional[12],tempat untuk meningkatkan perekonomian (Revene dan Sharon, 2008), dan tempat untuk mendapatkan penghidupan [13].

Persaingan untuk memperebutkan calon konsumen dan mempertahankan pelanggan yang sudah ada merupakan tantangan yang semakin besar dan harus dihadapi oleh pelaku usaha dalam memasarkan produknya. Keputusan pembelian konsumen diawali oleh keinginan membeli yang timbul karena terdapat berbagai faktor yang berpengaruh seperti keluarga, harga yang diinginkan, informasi yang diberikan, dan keuntungan atau manfaat yang bisa diperoleh dari produk atau jasa. Ketika konsumen melakukan pembelian, banyak faktor situasional yang bisa mempengaruhi keputusan pembeliannya.Produk merupakan elemen dasar yang sangat penting dari bauran pemasaran,dikatakan penting karena dengan produk 
perusahaan dapat menetapkan harga yang sesuai, mendistribusikan dan menentukan komunikasi yang tepat untuk pasar sasaran. Produk diciptakanuntuk memenuhi kebutuhan dan keinginan konsumen. Artinya produk adalah sesuatu yang diciptakan guna untuk memenuhi kebutuhan konsumen. Produk biasanya diikuti oleh serangkaian atribut-atribut yang menyertai suatu produk meliputi merek, kemasan, label, layanan pelengkap dan jaminan [14].

Selain produk, hal terpenting yang dapat menarik daya beli konsumen adalah lokasi yang dipilih sebagai tempat usaha. [7]menyatakan kunci menentukan lokasi yang perlu diperhatikan adalah mudah dijangkau, fasilitas parkir, tempat yang cukup, dan lingkungan yang nyaman. Lokasi usaha dapat juga disebut dengan saluran distribusi perusahaan karena lokasi juga berhubungan langsung dengan pembeli atau konsumen atau dengan kata lain lokasi juga merupakan tempat produsen menyalurkan produknya kepada konsumen serta merupakan komitmen sumber daya jangka panjang. Lokasi akan mempengaruhi pertumbuhan di masa depan karena area yang dipilih haruslah mampu untuk tumbuh dari segi ekonomi sehingga dapat mempertahankan kelangsungan hidup perusahaan. Keputusan pembelian konsumen akan produk yang diciptakan pasti memiliki pertimbangan salah satunya adalah harga [15];[16]. Harga merupakan suatu nilai yang dibuat untuk menjadi nilai suatu barang. Harga merupakan jumlah uang yang harus dibayarkan konsumen untuk mendapatkan suatu produk guna memenuhi kebutuhan dan keinginan yang belum terpuaskan [17]. Peranan harga tak lepas dari proses jual beli suatu produk dan jasa.

Pasar Landungari merupakan salah satu pasar tradisional yang ada di kecamatan Dau Kabupaten Malang, barang yang diperdagangkan sebagian besar termasuk kebutuhan primer, artinya barang yang masuk katagori kebutuhan sehariharisehingga menjadi pasar langanan ibu rumah tangga, mahasiswa dan warga. Lokasi yang strategis membuat ramai dikunjunggi oleh warga setempat maupun mahasiswa yang ingin membeli berbagai keperluan. Di lokasi tersebut juga terjadi transaksi tawar menawar yang dapat berakhir dengan keputusan pembelian produk yang diinginkan oleh konsumen.

\section{Keputusan Pembelian}

\section{KAJIAN TEORI}

Consumer buyer behavior refers to the buying behavior of final consumers-individuals and households that buy goods and services for personal consumption[18], untuk proses keputusan pembelian terdiri dari lima tahap sebagai berikut [19]:

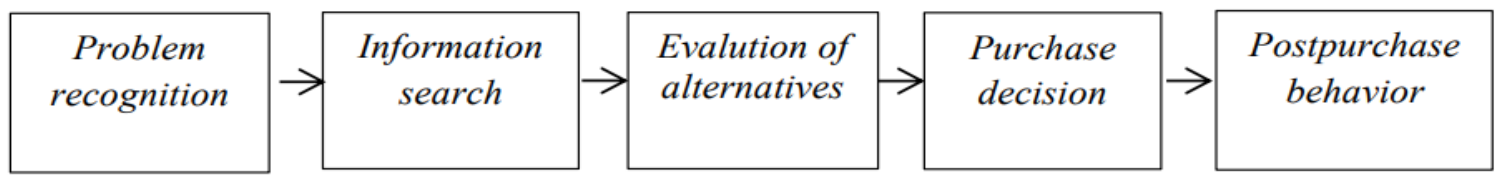

Gambar 1.Tahap Proses Keputusan Pembelian Konsumen. 


\section{Produk}

Produk adalah segala sesuatu yang ditawarkan ke pasar untuk mendapatkan perhatian, dibeli, dipergunakan dan yang dapat memuaskan keinginan atau kebutuhan konsumen [18]. Kualitas merupakan suatu kondisi dinamis yang berpengaruh dengan produk, jasa, manusia, proses dan lingkungan yang memenuhi atau melebihi harapan sehingga definisi kualitas pelayanan dapat diartikan sebagai upaya pemenuhan kebutuhan dan keinginan konsumen serta ketepatan penyampaiannya dalam mengimbangi harapan konsumen[20].

\section{Lokasi}

Definisi lokasi mengacu pada berbagai aktivitas pemasaran yang berusaha memperlancar dan mempermudah penyampaian atau penyaluran barang dan jasa dari produsen kepada konsumen [20]. Sedangkan pendapat lain menjelaskanPlace include company activities that make the product available to target consumers" [18]. Selanjutnya lokasi adalah keputusan yang dibuat perusahaan atau instansi pendidikan berkaitan dengan di mana operasi dan stafnya akan ditempatkan[21].

\section{Harga}

Harga adalah sejumlah uang yang dibebankan atas suatu produk atau jasa, atau jumlah dari nilai yang ditukar konsumen atas manfaat-manfaat karena memiliki atau menggunakan produk atau jasa tersebut [18]. Harga merupakan elemen bauran pemasaran yang dapat menghasilkan pendapatan melalui penjualan. Oleh karena itu, perusahaan harus dapat menetapkan harga produknya dengan baik dan tepat sehingga konsumen tertarik dan mau membeli produk yang ditawarkan agar perusahaan mendapatkan keuntungan.

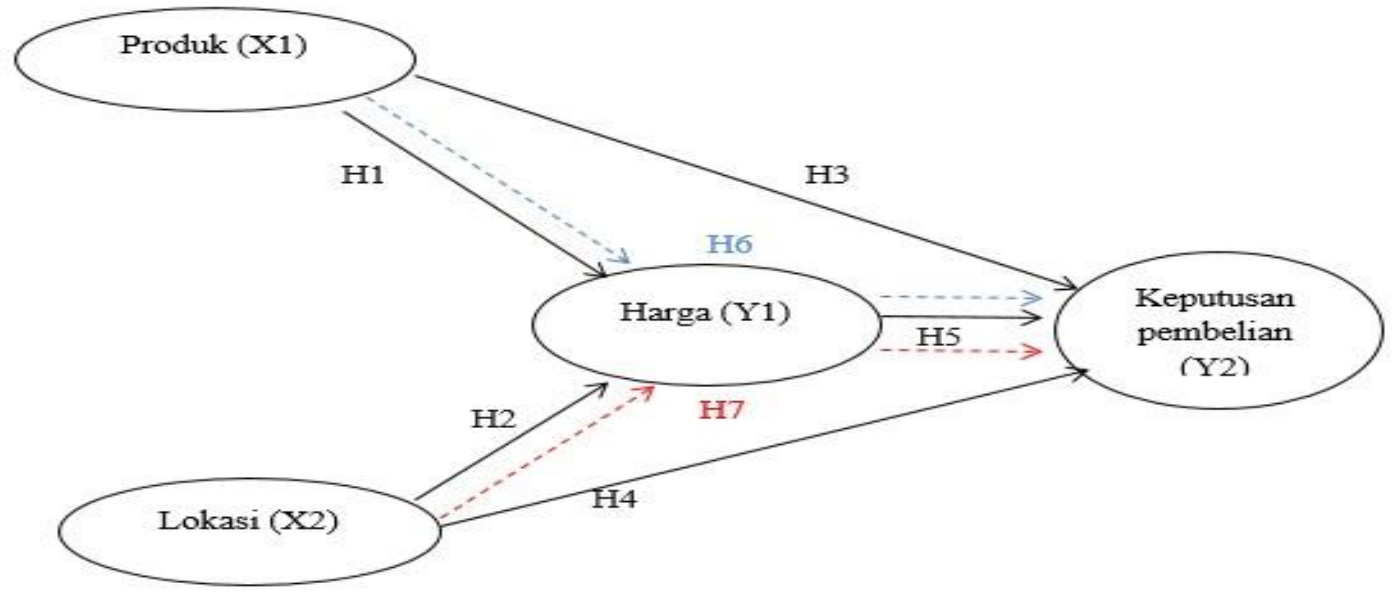

Gambar 2. Kerangka konseptual 
Dengan mengacu pada kerangka pemikiran maka hipotesis dirumuskan sebagai berikut:

$\mathrm{H}_{1}$ : Diduga variabel produk berpengaruh terhdap harga

$\mathrm{H}_{2}$ : Diduga variabel lokasi berpengaruh terhadap harga

$\mathrm{H}_{3}$ : Diduga variabel produk berpengaruh terhadap keputusan pembelian

$\mathrm{H}_{4}$ : Diduga variabel lokasi berpengaruh terhadap keputusan pembelian

$\mathrm{H}_{5}$ : Diduga variabel harga berpengaruh terhadap keputusan pembelian

$\mathrm{H}_{6}$ : Diduga variabel produk berpengaruh terhadap keputusan pembelian melalui harga

$\mathrm{H}_{7}$ : Diduga variabel lokasi berpengaruh terhadap keputusan pembelian melalui harga

\section{METODE PENELITIAN}

Data yang digunakan adalah data primer berupa hasil kuesioner yang disebarkan kepada pegawai Kantor Kementerian Agama OKU Timur. Variabel yang diteliti oleh peneliti ada dua yaitu variabel pertama adalah variabel bebas yang terdiri dari variabel iklim kerja dan pengarahan, sedangkan variabel yang kedua adalah variabel terikat yaitu variabel semangat kerja pegawai dengan melakukan tekhnik analisis data sebagai berikut :

\section{Tekhnik Analisis Data}

Skala Likert

R. S Likert mengembangkan prosedur penskalaan dimana skala mewakili suatu countinum bipolar, pada ujung sebelah kiri dengan angka rendah menggambarkan jawaban yang negative, sedangkan ujung sebelah kanan dengan angka besar / tinggi yang menggambarkan jawaban yang positif. Format likert dirancang untuk memungkinkan pelanggan menjawab dalam berbagai tingkatan pada setiap butir yang menguraikan variabel - variabel yang diteliti. Format Check List yang memberikan jawaban ( Ya ) atau ( Tidak) dengan kisaran skala antara 1 sampai dengan 5

1. Sangat Setuju (SS)

:Skor 5

2. Setuju (S)

: Skor 4

3. Kurang Setuju (KS)

:Skor 3

4. Tidak Setuju (TS)

: Skor 2

5. Sangat Tidak Setuju (STS)

:Skor 1

\section{Analisis Validitas}

Validitas menunjukkan tingkat yang digunakan sebagai bukti pendukung kesimpulan yang ditarik dari nilai yang diturunkan dari tingkat dimana skala mengukur sesuatu yang harus diukur. Suatu data dikatakan valid apabila nilai 
corrected item lebih besar dari nilai $\mathrm{r}$ tabel dengan $\mathrm{df}=\mathrm{n}-2$ atau Validitas instrument ketiga variabel dinilai dengan cara menghitung data dengan rumus Pearson Product Moment dalam program Komputer SPSS. Butir pernyataan/pertanyaan dinyatakan valid jika nilai Pearson Product Moment> $\mathrm{r}$ Tabel yang ditandai dengan $\left(^{*}\right)$ dan $\left(^{* *}\right)$. Angka kritis korelasi tabel (Tabel r) adalah 0,361 . Angka ini diperoleh dari tabel $r$-product moment pada taraf signifikansi $5 \%(\alpha=0,05)$ dan $\mathrm{N}=28$ (sesuai jumlah responden). Dengan demikian apabila ada koefisien korelasi butir pertanyaan / pernyataan berada dibawah 0,361 maka dinyatakan tidak valid.

\section{TEMUAN DAN PEMBAHASAN}

Dalam pengambilan data penelitian kepada responden menggunakan instrumen sebagi alat mengambil data primer,uji validitas tehadap instriumen yang hasilnya untuk variabel produk, lokasi, harga dan keputusan pembelian, semua variabel dinyatakan validkarena nilai $\mathrm{r}$ hitungnya $>0,220$. Untuk uji reliabilitas hasilnya menujukkan semua variabel adalah reliabel karena nilai alphapada masing-masing variabel $>0,6$. Hal tersebut dapat diartikan bahwa responden memiliki jawaban yang konsisten atau stabil dari waktu ke waktu sehingga kuesioner tersebut memiliki isi yang tidak akan berubah apabila digunakan kembali untuk waktu yang akan datang dan untuk menjelaskan item yang sama.

Data yang telah dikumpulkan sebelum dianalisisdilakukan uji asumsi normalitas dimana hasilnya grafik normal plot terlihat titik-titik menyebar disekitar diagonal, serta penyebarannya mengikuti garis diagonal, kondisi ini menunjukkan bahwa model regresi layak dipakai karena memenuhi asumsi normalitas.Untuk uji asumsi heterokedasitas adalah dengan melihat pada grafik scatterplot antara nilai prediksi variabel terikat dengan residualnya diperoleh hasil tidak adanya pola yang jelas, serta titik-titik menyebar di atas dan di bawah angka Opada sumbu ysehinggadapat disimpulakan tidak terjadi heteroskedastisitas.Selanjutnya untuk uji asumsi multikolinieritas menujukkan tidak terdapat multikolonieritas, hal ini dapat dilihat dari nilai tolerance yang nilainya lebih besar dari 0,1 yaitu 0,260 dan nilai VIF yang kurang dari 10 yaitu 3,842. Variabel Lokasi mempunyai nilai tolerance yang nilainya lebih besar dari 0,1 yaitu 0,154 dan nilai VIF yang kurang dari 10 yaitu 6,502. Variabel Harga mempunyai nilai tolerance yang nilainya lebih besar dari 0,1 yaitu 0,179 dan nilai VIF yang kurang dari 10 yaitu 5,580,sehingga model regresi yang digunakan adalah memenuhi dari seluruh asumsi yang diperlukan.

Selanjutnya dilakukan analisis verivikatif yang digunakan untuk menguji konstruk jalur apakah teruji secara empiris atau tidak, analisis verifikatif dilakukan untuk mengetahui hipotesis diterima atau ditolak dapat dilakukan dengan memperhatikan nilai signifikansi antar konstruk, t-tatistik dan p-value. Melalui cara tersebut, estimasi pengukuran dan standar error tidak lagi dihitung dengan asumsi 
statistik, tetapi didasarkan pada observasi empiris hasilnyadapat disajikan dalam gambar sebagai berikut:

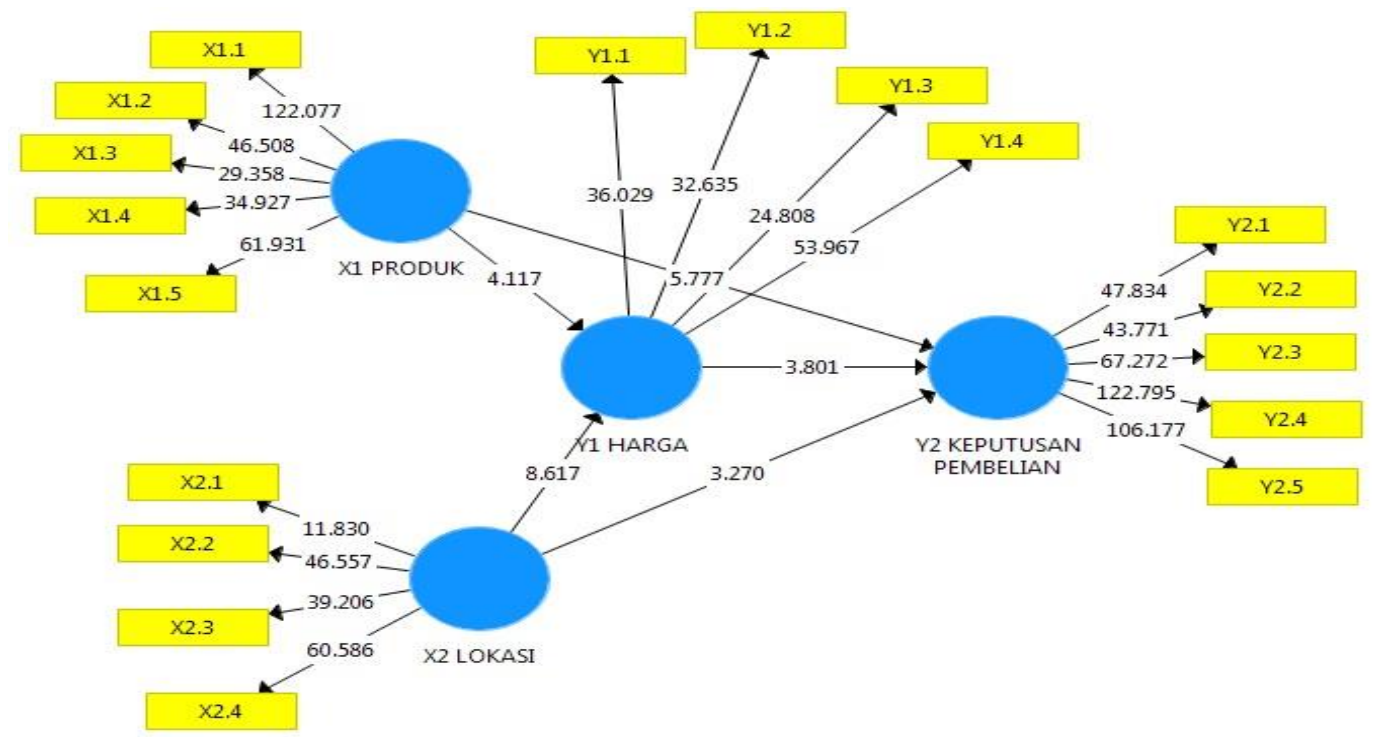

Gambar 3.Diagram Konstruk Analisis Verivikatif

Untuk menguji hipotesis menggukan ketentuan hipotesis dapat diterima apabila nilai signifikansi $t$-values $>\mathrm{t}$-tabel dan atau nilai $p$-values< 0.05 , maka $\mathrm{Ha}$ diterima dan Ho ditolak begitu pula sebaliknya.Nilai $t$ tabel memperhatikan degree of fredom(df) dengan signifikansi yang telah ditentukan yaitu 5\%, dimana berdasarkan hasil pengujian maka hasilnya dapat disajikan tabel berikut:

Tabel 1. Hasil pengujian Path Coefficient.

\begin{tabular}{lccccc}
\hline Konstruk & $\begin{array}{c}\text { Original } \\
\text { Sample } \\
(O)\end{array}$ & $\begin{array}{c}\text { Sample } \\
\text { Mean }(M)\end{array}$ & $\begin{array}{c}\text { Standard } \\
\text { Deviation }\end{array}$ & $\begin{array}{c}\text { T Statistics } \\
(\mid \mathrm{O} / \text { STDEV|) }\end{array}$ & P Values \\
\hline X1 Produk -> Y1 Harga & 0,323 & 0,322 & 0,079 & 4,117 & 0,000 \\
X2 Lokasi -> Y1 Harga & 0,656 & 0,657 & 0,076 & 8,617 & 0,000 \\
X1 Produk -> Y2 Kep. Pembelian & 0,407 & 0,403 & 0,071 & 5,777 & 0,000 \\
X2 Lokasi -> Y2 Kep. Pembelian & 0,268 & 0,273 & 0,082 & 3,270 & 0,001 \\
Y1 Harga -> Y2 Kep. Pembelian & 0,328 & 0,328 & 0,086 & 3,801 & 0,000 \\
\hline
\end{tabular}

Sumber : Hasil Olah Data dengan Smart-PLS (2020)

Berdasarkan tabel 1menujukkan konstruk variabel produk mempunyai pengaruh $\mathrm{O}=0.323$ dengan konstruk variabel harga. Nilai $t-$ statistic pada hubungan konstruk ini adalah 4,117 > t-tabel 1,990 dan nilai $p$-value $0,000<$ standard error 0,05,makadapat disimpulkan produk berpengaruh positif terhadap harga sehingga hipotesis pertama diterima.Konstruk variabel lokasi mempunyai pengaruh $\mathrm{O}=0.656$ dengan konstruk variabel harga. Nilai t-hitung pada hubungan konstruk ini adalah 8,617 > t-tabel 1,990 dan nilai $p$-value $0,000<$ standard error 0,05 ,sehingga lokasi 
berpengaruh positif signifikan terhadap harga, maka hipotesis kedua diterima.Konstruk variabel produk mempunyai pengaruh $\mathrm{O}=0.407$ dengan konstruk varaiebl keputusan pembelian Y2. Nilai t-hitung pada hubungan konstruk ini adalah 5,777 > t-tabel 1,990 dan nilai $\mathrm{p}$ - value $0,000<$ standard error 0,05, sehingga produk berpengaruh positif signifikan terhadap keputusan pembelian,maka hipotesis ketiga diterima.Konstruk variabel lokasi mempunyai pengaruh $\mathrm{O}=0,268$ dengan konstruk keputusan pembelian. Nilai $\mathrm{t}$ - hitung pada hubungan konstruk ini adalah 3,270 >ttabel 1,990 dan nilai p-value 0,001 <standard error 0,05,sehingga lokasi berpengaruh positif signifikan terhadap keputusan pembelian, maka hipotesis keempat diterima.Konstruk variabel harga mempunyai pengaruh $\mathrm{O}=0,328$ dengan konstruk keputusan pembelian. Nilai t-hitung pada hubungan konstruk ini adalah 3,801 >ttabel 1,990 dan nilai $p$ - value 0,000 <standard error 0,05 ,sehingga harga berpengaruh positif signifikan terhadap keputusan pembelian, maka hipotesis kelima landungsari diterima.

Untuk mengetahui hubungan tidak langsung yaitu variabel harga mampu memediasi hubungan antara produk dan lokasi terhadap keputusan pembelian maka dialkukan uji spesific indirect effects yang hasilnya dapat dilihat pada tabel 2.

Tabel 2.Hasil uji specific indirect effects.

\begin{tabular}{lccccc}
\hline \multicolumn{1}{c}{ Konstruk } & $\begin{array}{c}\text { Original } \\
\text { Sample } \\
(O)\end{array}$ & $\begin{array}{c}\text { Sample } \\
\text { Mean } \\
(M)\end{array}$ & $\begin{array}{c}\text { Standard } \\
\text { Deviation } \\
(\text { STDEV })\end{array}$ & $\begin{array}{c}\text { T Statistics } \\
(\mid \text { OSTDEV|) }\end{array}$ & P Values \\
\hline $\begin{array}{l}\text { X1 Produk -> Y1 Harga } \\
\begin{array}{l}\text { Y2 Kep. Pembelian } \\
\text { X2 Lokasi -> Y1 Harga -> Y2 Kep. }\end{array}\end{array}$ & 0,106 & 0,106 & 0,040 & 2,659 & 0,008 \\
Pembelian & 0,215 & 0,215 & 0,061 & 3,534 & 0,000 \\
\hline
\end{tabular}

Sumber : Hasil Olah Data dengan Smart-PLS (2020)

Berdasarkan tabel 2 terdapat pengaruh $\mathrm{O}=0,106$ antara produk dengan keputusan pembelian yang dimediasi oleh harga. Nilai t-hitung pada hubungan konstruk ini adalah 2,659>t-tabel 1,990 dan nilai $p$-value 0,008 <standard error 0,05. Sehingga produk berpengaruh positif signifikan terhadap keputusan pembelian yang dimediasi oleh harga. Hal ini berarti bahwa variabel harga berperan sebagai partial control. Partial control berarti bahwa dalam hubungan antar variabel terdapat hubungan langsung dan tidak langsung (Garson, 2016). Berdasarkan hasil tersebut, maka hipotesis keenam diterima.

Variabel lokasi mempunyai pengaruh $\mathrm{O}=0,215$ terhadap keputusan pembelian melalui variabel harga. Nilai t-hitung pada hubungan konstruk ini adalah $3,534>t$ tabel 1,990 dan nilai $p$-value $0,000<$ standard error 0,05 . Sehingga lokasi berpengaruh positif signifikan terhadap keputusan pembelian yang dimediasi oleh harga. Hal ini berarti bahwa variabel harga berperan sebagai partial control. Berdasarkan hasil tersebut, maka hipotesis ketujuh diterima.Berdasrkan hasil tersebut maka dapat 
disimpulkan pengaruh produk dan lokasi terhadap keputusan pembelian melalui harga sebagai veriabel intervening yang secara keseluruhan hasilnya dapat disajikan pada gambar 4 .

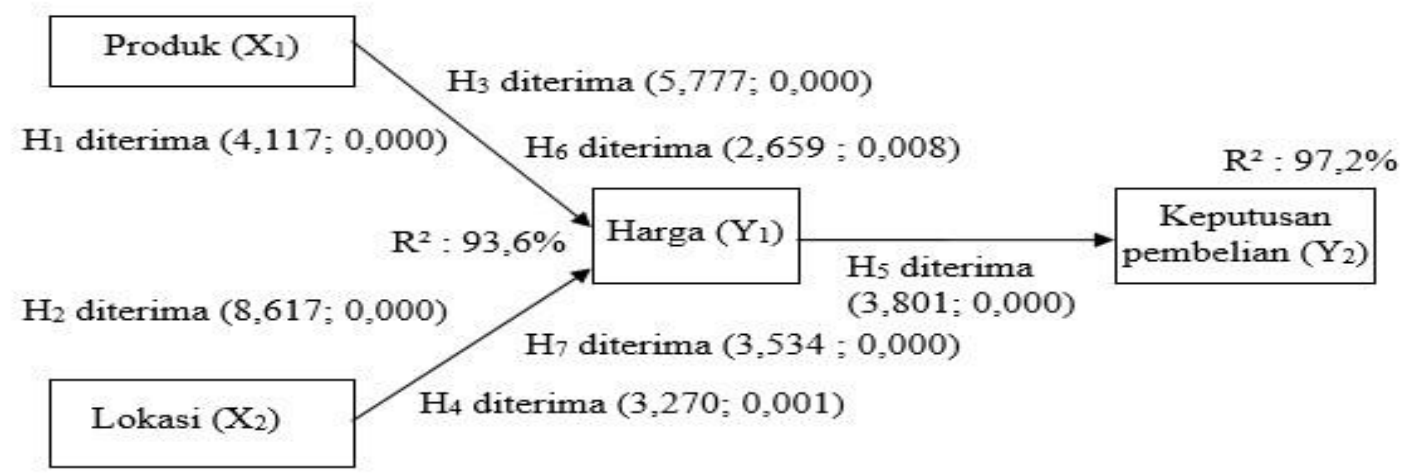

Gambar 4. Hasil pengujian hipotesis

\section{Pengaruh Produk Terhadap Harga}

Hasil penelitian membuktikan bahwaprodukberpengaruh terhadap harga, dimanaproduk yang mempengaruhi harga seperti produk yang dijual sesuai dengan harga dan kualitas, produk yang dijual beragam, segar atau baru, tidak ada yang cacat, menjual produk yang berbeda dengan produk pedagang lain, menjual produk yang bersih dan aman dikonsumsi, serta tidak mengandung bahan pengawet.Produk berpengaruh terhadap harga hasil ini disebabkan produk yang ditawarkan sangat bervariasi. Satu jenis produk yang sama dijual oleh banyak pedagang, setiap pedagang menetapkan harga yang berbeda sesuai kualitas yang ditawarkan. Semakin baik kualitas yang ditawarkan maka semakin tinggi pula harga yang ditetapkan kepada konsumen.Hasil penelitian ini sesuai dengan penelitianterdahulu yang membuktikan bahwa produk yang berkualitas berperan penting menentukan harga jual[24]. Produk sebagai segala sesuatu yang ditawarkan ke pasar untuk mendapatkan perhatian, dibeli, dipergunakan dan yang dapat memuaskan keinginan atau kebutuhan konsumen. Produk yang berkualitas baik akan memiliki harga yang tinggi karena memperhatikan kebutuhan konsumen. Produk yang baik seperti memiliki merek, memiliki kemasan yang rapi dan bisa menjamin kebersihannya. Kualitas produk yang terjaga dan harga yang ditawarkan sesuai dengan harapan konsumen akan membuat konsumen merasa puas dan menerima suatu produk bahkan menjadi loyal terhadap produk.

\section{Pengaruh LokasiTerhadap Harga}

Hasil analisis yang telah disajikan membuktikan bahwa lokasiberpengaruh terhadap harga. Lokasi yang mempengaruhi harga seperti lokasi di pasar sehingga harga bersaing dengan pedagang lain, semakin bersih lokasi akan mendukung 
peningkatan harga, lokasi bisa di jangkau semua masyarakat dengan mudah dan lokasi berada di lingkungan padat penduduk.Lokasi berpengaruh terhadap harga hasil ini disebabkan lokasi pasar Landungsari cukup strategis. Walaupun lokasi tidak terletak di jalan utama namun lokasi sangat dekat perkampungan. Selain itu lokasi juga masih dekat dengan pasar induk yaitu karang ploso. Sehingga kedekatan pasar landungsari dengan pasar karang ploso itulah yang membuat harga produk relatif murah. Karna pedagang untuk memperoleh produk yang dijual tidak terlalu mengeluarkan biaya transportasi.Hasil penelitian ini sesuai dengan penelitian terdahulu yang menyatakan dengan tingginya harga mengindikasikan bahwa lokasi tersebut sangat strategis untuk kegiatan usaha sehingga banyaknya peminat yang menjadikan penyebab tingginya harga sebuah lokasi usaha[25]. Lokasi mengacu pada berbagai aktivitas pemasaran yang berusaha memperlancar dan mempermudah penyampaian atau penyaluran barang dan jasa dari produsen kepada konsumen. Pentingnya lokasi bagi pengusaha sangat mempengaruhi keputusan sasaran pasar dalam menentukan keputusan pembeliannya. Faktor kunci dalam menentukan lokasi yaitu lokasi mudah dijangkau, ketersediaan lahan parkir, tempat yang cukup dan lingkungan sekitar yang nyaman.

\section{Pengaruh Produk terhadap Keputusan Pembelian Konsumen}

Hasil analisis yang telah disajikan membuktikan bahwa produk berpengaruh terhadap keputusan pembelian. Produk yang mempengaruhi keputusan pembelian seperti semakin produk berkualitas baik akan meningkatkan keputusan pembelian oleh konsumen karena yakin bahwa produk aman di konsumsi atau digunakan. Produk berpengaruh terhadap keputusan pembelian. Hasil ini disebabkan konsumen selalu melihat terlebih dahulu barang yang akan dibeli. Konsumen selalu membandingkan kualitas produk yang ditawarkan pedagang satu dengan lainnya. Sehingga produk dilihat dari kualitasnya bisa mempengaruhi keputusan pembelian.Hasil penelitian ini sesuai dengan penelitianterdahulu yang menjelaskan kualitas produk berpengaruh terhadap keputusan pembelian, dimana produk yang berkualitas akan meningkatkan minat seseorang untuk membeli produk[26]; [27].Hal ini berarti produk yang dijual berkualitas mampu meningkatkan keputusanpembelian suatu produk sehingga akan meningkatkan pendapatan. Kualitas produk diketahui dari bentuk produk bersih, memiliki rasa enak, segar, bisa digunakan dengan waktu yang cukup lama dan tidak mengandung bahwan pengawet. Pedagang yang menjual produk berkualitas akan meningkatkan loyalitas konsumen untuk membeli produk secara berulang-ulang karena merasa puas dengan produk yang di beli. Produk yang berkualitas dengan harga yang terjangkau akan memiliki banyak peminat. 


\section{Pengaruh Lokasi terhadap Keputusan Pembelian}

Hasil analisis yang telah disajikan membuktikan bahwalokasi berpengaruh terhadap keputusan pembelian. Lokasi mempengaruhi keputusan pembelian seperti letak pasar Landungsari dekat dengan keramaian warga, pasar Landungsari di lewati oleh angkutan umum, mudah dijangkau oleh masyarakat dan tempat parkir di pasar sudah cukup luas dan memadai.Lokasi berpengaruh terhadap keputusan pembelian. Hasil ini disebabkan pasar Landungsari sangat dekat dengan pemukiman warga. Sehingga konsumen yang lokasinya tidak jauh dari pasar Landungsari tidak ada pilihan lain untuk berbelanja selain disitu.Hasil inisejalan dengan penelitianterdahulu yang menjelaskan bahwa lokasi berperan penting terhadap keputusan pembelian, dimana lokasi yang dekat dan mudah dijangkawi konsumen akan meningkatkan minat membeli produk[7]; [28]. Indikator dari lokasi yaitu keterjangkauan, kelancaran, kedekatan dengan kediamannya dan tempat parkir yang luas, nyaman, dan aman baik untuk kendaraan roda dua maupun roda empat. Lokasi menjadi salah satu faktor yang mempengaruhi keputusan pembelian. Konsumen cenderung memilih lokasi yang mudah dijangkau dibandingkan lokasi yang sulit untuk menjangkaunya karena jauh. Lokasi yang mudah dijangkau dapat memberikan manfaat berupa efisiensi waktu dan tenaga. Lokasi berhubungan dengan rasa aman dan nyaman serta memiliki area parkir yang luas juga menjadi pilihan konsumen karena dapat memberikan kepuasan yang lebih bagi konsumen.

\section{Pengaruh Harga terhadap Keputusan Pembelian}

Hasil penelitian membuktikan bahwa harga berpengaruh terhadap keputusan pembelian. Harga yang mempengaruhikeputusan pembelian yaitu harga produk murah sesuai kualitas produk, harga produk mampu bersaing dengan produk lain, harga produk mampu dijangkawi semua kalangan dan harga produk stabil. Harga berpengaruh terhadap keputusan pembelian. Hasil ini disebabkan harga yang ditawarkan antara pedagang satu dan lainnya sangat bervariasi. Sedangkan harga melakukan keputusan pembelian dengan mempertimbangkan harga produk yang disesuaikan dengan uang yang dimiliki.Hasil penelitian ini sesuai dengan penelitianterdahulu yang menjelaskan harga produk yang sesuai kualitasnya akan meningkatkan minat konsumen dalam menentukan keputusan pembelian secara tepat[27];[28]. Harga sebagai bentuk sejumlah uang yang dibebankan atas suatu produk atau jasa, atau jumlah dari nilai yang ditukar konsumen atas manfaatmanfaat karena memiliki atau menggunakan produk atau jasa tersebut. Harga merupakan elemen bauran pemasaran yang dapat menghasilkan pendapatan melalui penjualan. Oleh karena itu, perusahaan harus dapat menetapkan harga produknya dengan baik dan tepat sehingga konsumen tertarik dan mau membeli produk yang ditawarkan agar perusahaan mendapatkan keuntungan. Harga merupakan faktor penting yang menjadi pertimbangan konsumen dalam membuat keputusan pembelian pada suatu bisnis. Konsumen menginginkan harga produk 
yang sesuai dengan kualitas dari produk yang bersangkutan. Penetapan harga oleh pelaku bisnis harus disesuaikan dengan lingkungan dan perubahan yang terjadi.

\section{Pengaruh Produk terhadap Keputusan Pembelian}

Hasil penelitian membuktikan bahwa produk berpengaruh terhadap keputusan pembelian melalui harga. Produk yang mempengaruhi keputusan pembelian melalui harga seperti produk memiliki harga murah sesuai kualitas, produk mampu dibeli siapa saja dan produk sesuai dengan harga yang ditetapkan dengan pedagang lain sehingga mempu meningkatkan keputusan pembelian konsumen. Produk berpenaruh terhadap keputusan pembelian melalui harga. Hasil ini disebabkan konsumen pasar Landungsari mempertimbangkan kualitas produk sesuai dengan harga produk kemudian juga dengan uang yang dimiliki. Semakin baiknya kualitas produk dan dengan harga yang murah konsumen akan mudah melakukan keputusan pembelian.Hasil penelitian ini sesuai penelitianterdahulu yang menjelaskan bahwa produk yang berkualitas baik memiliki harga yang tinggi dan sebaliknya produk yang memiliki kualitas rendah memiliki harga yang rendah juga[4]; [29]. Faktor produk dan harga merupakan dua faktor yang mempengaruhi pertimbangan konsumen dalam keputusan pembelian. Faktor produk sendiri merupakan hal yang diperhatikan konsumen dalam mengambil keputusan. Produk yang dijual harus mempunyai kualitas yang baik, unik dan penampilan yang menarik sehingga dapat membuat konsumen tertarik untuk membeli. Kualitas produk yang baik akan mendorong perusahaan untuk mempertahankan usahanya dan mampu bersaing dengan pesaing lainnya. Selain faktor produk, harga juga merupakan faktor yang penting. Penentuan harga produk yang dilakukan perusahaan sangatlah berpengaruh pada keputusan konsumen.

\section{Pengaruh Lokasi terhadap Keputusan Pembelian melalui Harga}

Hasil penelitian membuktikan bahwa lokasi berpengeruh terhadap keputusan pembelian melalui harga. Lokasi yang mempengaruhi keputusan pembelian melalui harga seperti lokasi yang dekat dengan pemukiman dan harga yang murah mampu meyakinkan keputusan konsumen membeli produk. Lokasi berpengaruh terhadap keputusan pembelian melalui harga. Hasil ini disebabkan harga yang ditawarkan oleh pedagang pasar relatif terjangkau dan lokasi pun juga sangat dekat dengan konsumen. Selain itu lokasi penelitianyang dekat dengan para pelaku usaha makanan dan minuman, hal itulah yang membuat keputusan pembelian konsumen mempertimbangkan lokasi dan harga produk.Hasil penelitian ini sesuai penelitianterdahulu yang menjelaskan bahwa lokasi usaha yang dekat dengan pemukiman penduduk dan memiliki harga yang murah akan mendukung peningkatan keputusan konsumen membeli produk[30]; [29].Lokasi mempunyai fungsi yang strategis karena dapat ikut menentukan tercapainya tujuan badan usaha. Harga merupakan komponen yang berpengaruh langsung terhadap proses 
penentuan dimana seorang akan berbelanja. Keputusan pembelian sebagai suatu proses pengambilan keputusan akan pembelian yang mencakup penentuan apa yang akan dibeli atau tidak melakukan pembelian dan keputusan itu diperoleh dari kegiatan-kegiatan sebelumnya.

\section{KESIMPULAN DAN SARAN}

Produk yang mempengaruhi harga seperti produk yang dijual sesuai dengan harga dan kualitas, produk yang dijual beragam, segar atau baru, tidak ada yang cacat, menjual produk yang berbeda dengan produk pedagang lain, menjual produk yang bersih dan aman dikonsumsi, serta tidak mengandung bahan pengawet.Produk yang mempengaruhi keputusan pembelian seperti semakin produk berkualitas baik akan meningkatkan keputusan pembelian oleh konsumen karena yakin bahwa produk aman di konsumsi atau digunakan.Lokasi yang mempengaruhi harga seperti lokasi sehingga harga bersaing dengan pedagang lain, semakin bersih lokasi akan mendukung peningkatan harga, lokasi bisa di jangkau semua masyarakat dengan mudah dan lokasi berada di lingkungan padat penduduk.Lokasi mempengaruhi keputusan pembelian seperti letak dekat dengan keramaian warga, di lewati oleh angkutan umum, mudah dijangkau dan tempat parkir cukup luas dan memadai. Lokasi yang mempengaruhi keputusan pembelian melalui harga seperti lokasi yang dekat dengan pemukiman dan harga yang murah mampu meyakinkan keputusan konsumen membeli produk.Harga yang mempengaruhikeputusan pembelian yaitu harga produk murah sesuai kualitas produk, harga produk mampu bersaing dengan produk lain, harga produk mampu dijangkau semua kalangan dan harga produk stabil.Produk yang mempengaruhi keputusan pembelian melalui harga seperti produk memiliki harga murah sesuai kualitas, produk mampu dibeli siapa saja dan produk sesuai dengan harga yang ditetapkan dengan pedagang lain sehingga mempu meningkatkan keputusan pembelian konsumen.

\section{DAFTAR PUSTAKA}

A. Ferdinand, Metode Penelitian Manajemen, Semarang: Badan Penerbit Universitas Diponegoro, 2016.

A. Ferdinand, Metode Penelitian Manajemen, Semarang: Badan Penerbit Universitas Diponegoro, 2016.

A. Prastawan, A. Suryono, M. S. Soeady dan K. Muluk, "Revitalization of Traditional Markets intoa Modern Market in thePerspective of Local Governance Theory," OSR Journal Of Humanities And Social Science, vol. 20, no. 9, pp. 1-6,

A. Prastawan dan P. Isbandono, "The role of local governments in traditional market revitalization," Journal of Physics: Conference Series, vol. 953, no. 1, 2018. 
A. A. Ulus, "Bauran Pemasaran Pengaruhnya Terhadap Keputusan Pembelian Mobil Daihatsu pada PT. Astra Internasional Manado," Jurnal EMBA: Jurnal Riset Ekonomi, Manajemen, Bisnis dan Akuntansi, vol. 1, no. 4, pp. 1134-1144, 2013.

B. Sheehy, "Corporations and social costs: The Wal-Mart case study," Journal Law $\mathcal{E}$ Commerce, vol. 24, no. 1-50, p. 1, 2004.

D. Toksoy, M. Bayramoglu dan S. Hacisalihoglu, "Usage and the economic potential of the medicinal plants in Eastern Black Sea Region of Turkey," Journal of Environmental Biology, vol. 31, no. 5, pp. 623-628, 2010.

D. Irawan dan E. Japarianto, “Analisa Pengaruh Kualitas Produk Terhadap Loyalitas Melalui Kepuasan Sebagai Variabel Intervening pada Pelanggan Restoran Por Kee Surabaya," vol. 1, no. 2, pp. 1-8, 2013.

E. N. Fu'ad, "Pengaruh Pemilihan Lokasi Terhadap Kesuksesan Usaha Berskala Mikro/Kecil Di Komplek Shopping Centre Jepara," Media Ekonomi dan Manajemen, vol. 30, no. 1, pp. 56-67, 2016.

E. N. Fu'ad, "Pengaruh Pemilihan Lokasi Terhadap Kesuksesan Usaha Berskala Mikro/Kecil Di Komplek Shopping Centre Jepara," Media Ekonomi dan Manajemen, vol. 30, no. 1, pp. 56-67, 2016

E. Prabowo, S. Mardi dan P. Lustrilanang, "Existence and Revitalization of Traditional Markets Against Modern Markets Development," IOSR Journal of Humanities And Social Science, pp. 2090-4304, 2017.

E. Sadilah, Eksistensi Pasar Tradisional (Relasi dan jaringan Pasar Tradional di Kota Semarang Jawa tengah), Yogyakarta: BPNST, 2011.

F. Tjiptono, Pemasaran Jasa, Yogyakarta: Andi Ofset, 202

F. Tjiptono, Strategi Pemasaran, Yogyakarta: Andi Ofset, 2015.

H. Fure, "Lokasi, Keberagaman Produk, Harga, dan Kualitas Pelayanan pengaruhnya Terhadap Minat Beli pada Pasar Tradisional Bersehati Calaca," EMBA, vol. 1, no. 1, pp. 273-283, 2013.

H. Malano, Selamatkan Pasar Treadisinoal: Poteret Ekonomi Rakyat Kecil, Jakarta: PT Gramedia Putaka Utama, 2011.

I. Gozali, Aplikasi Analisis Multivariate dengan Program IBM SPSS 21 Update PLS Regresi, Semarang: Badan Penerbit Universitas Diponegoro, 2016.

I. Hariyotejo, "Analisis Pengaruh Produk, Harga, Distribusi, dan Prmosi Terhadap Keputusan Pembelian serta Implikasinya pada Kepuasan Pelanggan," Journal Ekonomi, Bisnis E Entrepreurship, vol. 9, no. 2, pp. 80-101, 2014.

J. W. Nelwan, S. L. J. Lapian dan F. S. Rumokoy, "The existence of traditional market toward modern market in Tomohon City," Jurnal EMBA: Jurnal Riset Ekonomi, Manajemen, Bisnis dan Akuntansi, vol. 5, no. 3, pp. 3348-3355, 2017.

M. A. Palma dan A. L. Andjarwati, “Pengaruh Kualitas Produk, Kemudahan,dan Harga Terhadap Niat Beli Ulang dengan Kepuasan Sebagai Variabel Intervening (Studi Pada Pelanggan Produk Fashion Melalui Toko online di Surabaya)," Jurnal Riset Ekonomi dan Manajemen, vol. 16, no. 1, pp. 84-104, 2016. 
P. Kotler dan G. Amstrong, Principles of Marketing, Jakarta: Erlangga , 2014.

P. Kotler dan K. L. Keller, Marketing Management, Perasong Education, Inc, 2016, p. 195.

R. Lopiyoadi dan A. Hamdani, Manajemen Pemasaran Jasa, vol. Kedua, Jakarta: Salemba Empat, 2011.

R. Lopiyoadi dan A. Hamdani, Manajemen Pemasaran Jasa, vol. Kedua, Jakarta: Salemba Empat, 2011.

S. Lee, C. Xiao dan P. Sengji, "Ethnobotanical survey of medicinal plants at periodic markets of Honghe Prefecture in Yunnan Province, SW China," Journal of Ethnopharmacology, vol. 117, no. 2, pp. 362-377, 2008.

S. Zulaicha dan R. Irawati, "Pengaruh Produk dan Harga terhadap Keputusan Pembelian Konsumen di Morning Bakery Batam," Jurnal Inovasi dan Bisnis, vol. 4, no. 2, pp. 125-136, 2016.

S. A. Mimi, "Pengaruh Harga, Kualitas Pelayanan, Lokasi dan Keragaman Produk Terhadap Keputusan Pembelian di Ranch Market," . Jurnal Ekonomi, vol. 20, no. 1, pp. 89-102., 2015.

S. Bakhri, "Strategy for Increasing Traditional Market Cpmparativness in Dealing With the Presence of Modern Market," Jurnal Eko-Regional: Penembangan Ekonomi Wilayah, vol. 12, no. 1, pp. 9-17, 2017.

S. S. \&. W. D. Hermuningsih, "Development Strategy Analysis: Creative Industry," Journal of Yogyakarta City BAPPEDA Research, pp. 143-153, 2016. 